\title{
Strategi Kurikulum 2013 Dalam Mengembangkan Daya Kritis Generasi Z
}

\author{
Al Manaf ${ }^{1}$, Tasman Hammami ${ }^{2}$ \\ ${ }^{1,2}$ Universitas Islam Negeri Sunan Kalijaga Yogyakarta, Indonesia
}

\begin{tabular}{l}
\hline \multicolumn{1}{c}{ INFO ARTIKEL } \\
\hline Riwayat Artikel: \\
Diterima: $02-11-2020$ \\
Disetujui: $31-12-2020$ \\
Diterbitkan: $31-12-2020$
\end{tabular}

\section{Kata kunci:}

Kurikulum 2013

Daya Kritis

Generasi Z

\footnotetext{
Alamat Korespondensi:

Al Manaf

Program Studi Pendidikan Agama Islam

Universitas Islam Negeri Sunan Kalijaga Yogyakarta

E-mail: 19204010015@student.uin-suka.ac.id
}

Abstract: The purpose of this research is to find out and analyze curriculum strategies in developing critical power generation Z this is due to complex future challenges related to globalization and free markets, environmental problems, advances, in information technology, convergence, of science and teechnology, knowledge based economics, the advancement of creative and cultural industries, the influence of technology, quality investment and transformation in the education sector. This study uses the Library Research approach by conducting a literature review. As for the results of his research in the 2013 curriculum as a design that is used in the era of technology for the creation of a generation of technologists who play a role both in the real world and in cyberspace as the next generation of the nation and the progress of the nation it self. Strategies used in developing and shaping the critical power of students are Problem Based Learning as a method in helping children to develop thinking skills, overcome problems, investigation skills and the ability to learn the role of adults through involvement in real experiences or simulations and Cooperative Learning as a method that are constructivist in which students are demanded and build knowledge independently.

\begin{abstract}
Abstrak: Tujuan penelitian ini untuk mengetahui dan menganalisis strategi kurikulum dalam mengembangkan daya kritis generasi Z. Hal ini disebabkan adanya tantangan masa depan yang kompleks berkaitan dengan globalisasi dan pasar bebas, masalah lingkungan hidup, kemajuan teknologi informasi, konvergensi ilmu dan teknologi, ekonomi yang berbasis pengetahuan, kemajuan industri kreatif dan budaya, pengaruh teknosains, mutu, investasi dan transformasi pada sektor pendidikan. Penelitian ini menggunakan pendekatan Library Research dengan melakukan kajian literatur. Adapun hasil penelitiannya ialah kurikulum 2013 sebagai rancangan yang digunakan dalam masa teknologi demi terciptanya generasi teknolog yang berperan baik dalam dunia nyata maupun dalam dunia maya sebagai penerus generasi bangsa dan kemajuan bangsa itu sendiri. Strategi yang digunakan dalam mengembangkan dan membentuk daya kritis.
\end{abstract}

\section{LATAR BELAKANG}

Kurikulum merupakan konsep strategis dalam meningkatkan taraf hidup manusia. Konsep kurikulum dalam dunia pendidikan sangat penting untuk meningkatkan kecerdasan, sikap dan skill peserta didik yang baik sesuai dengan kemampuan peserta didik masing-masing. Disamping itu, kurikulum juga harus dilakukan secara sistematis dan terarah yang sesuai dengan visi dan misi yang memunculkan pertanyaan "mau dibawa kemana system pendidikan nasional dengan kurikulum tersebut”. Pendidikan dalam Undang -Undang Republik Indonesia nomor 20 tahun 2003 tentang Sistem Pendidikan Nasional menyebutkan bahwa "pendidikan ialah usaha sadar dan terencana untuk mewujudkan suasana belajar dan proses pembelajaran agar peserta didik secara aktif mengembangkan potensi 
dirinya untuk memiliki kekuatan spiritual keagamaan, pengendalian diri, kepribadian, kecerdasan dan akhlak mulia serta ketrampilan yang dibutuhkan untuk dirinya, masyarakat dan bangsa". Mengacu pada UU diatas, kurikulum KTSP belum mampu menjawab persoalan yang ada dalam dunia pendidikan dan terdapat kelemahan pada beberapa aspek dalam kurikulum tersebut. Disisi lain, kurikulum juga harus relevan sesuai dengan zaman. Sebab pendidikan selalu berhubungan dan apa yang terjadi dalam kehidupan manusia. Maka dari itu, perlu adanya perubahan atau pengembangan kurikulum dalam dunia pendidikan untuk menciptakan manusia yang berguna dalam kehidupannya.

Faktanya masih banyak peserta didik khususnya generasi $\mathrm{Z}$ yang belum memahami potensinya sendiri, minat dan bakatnya, pengembangan dirinya sendiri. Hal inilah yang kemudian menjadikan mereka stagnan bahkan tidak paham peran pendidikan terhadap diri mereka. Sebab pendidikan ialah bagian daripada pembentukan dan pengembangan diri seseorang sehingga menjadikan anak didik menjadi kritis dan melek terhadap sosial khususnya lingkungan hidup mereka masing-masing. Selain permasalahan diatas, peserta didik dihadapkan juga dengan tantangan masa depan yang kompleks berkaitan dengan globalisasi dan pasar bebas, masalah lingkungan hidup, kemajuan teknologi informasi, konvergensi ilmu dan teknologi, ekonomi yang berbasis pengetahuan, kemajuan industri kreatif dan budaya, pengaruh teknosains, mutu, investasi dan transformasi pada sektor pendidikan(atTaubany \& Suseno 2017).

Perlu diketahui bahwa pembelajaran terdahulu kurang efektif dilakukan sekarang, sebab kebutuhan generasi Z berbeda dengan kebutuhan dahulu. Maka, pendidikan perlu adanya desain yang baru sesuai dengan kebutuhan dan tantangan-tantangan yang akan dihadapi oleh generasi sekarang atau biasa kita sebut dengan generasi Z. Menurut (Nazila \& Jadid 2019) dalam penelitiannya mengatakan bahwa kurikulum 2013 berbasis pda pengembangan peserta didik dengan karakteristik proses pembelajarannya yang sistematis dan mampu menghadapi era disrupsi. Kurikulum 2013 juga menuntut pemahaman anak didik yang menyeluruh dan mampu memberikan kontribusi pada pengembangan skill peserta didik yang menjadikan mereka manusia yang aktif. Sedangkan menurut (Machali 1970) memaparkan adanya kebijakan perubahan kurikulum 2013 didasari oleh kompleksnya masalah yang akan dihadapi bangsa baik tantangan internal maupun eksternal dalam rangka mempersiapkan regenerasi yang produktif, kreatif, dan inovatif.

Penelitian diatas, telah membahas kebijakan kurikulum 2013 sebagai pembentukan karakteristik dan kebijakan kurikulum itu sendiri, adapun penelitian ini fokus pada penerapan strategi pembelajaran dalam membentuk daya kritis generasi $\mathrm{Z}$ guna mengembangkan individu sebagai penyiapan dalam menghadapi tantangan-tantangan yang kompleks baik secara internal maupun eksternal. Kehadiran kurikulum 2013 sebagai rangka dalam mengembangkan potensi peserta didik untuk menyiapkan generasi bangsa yang lebih dari sebelumnya. Hal ini dimulai dari perubahan-perubahan dalam proses pembelajaran yang awalnya hanya sebagai transformasi ilmu dari guru ke anak didik menjadi keduanya aktif dalam pembelajaran. Maka dari itu pentingnya membahas strategi apa yang yang disipakan dalam kurikulum 2013 sebagai peran untuk mengembangkan daya kritis manusia khususnya generasi Z dalam mempersiapkan diri untuk menghadapi tantangan baik bersifat internal maupun eksternal.

\section{METODE}

Penelitian ini menggunakan pendekatan studi pustaka atau library research. Penelitian kepustakaan tidak terjun langsung kelapangan atau biasa dikatakan sebagai penelitian kualitatif dengan mengumpulkan, menganalisis, mengolah dan menyajikan buku, jurnal dan teks-teks yang berhubungan dengan tema penelitian sebagai bahan refrensi dalam bentuk laporan kepustakaan. Penelitian ini dilakukan untuk menganalisis strategi kurikulum 2013 dalam mengembangkan daya kritis generasi Z . Adapun pokok pembahasannya yaitu Pengembangan kurikulum 2013, kurikulum 2013 berbasis kompetensi dalam mengembangkan daya kritis generasi Z, metode dalam mengembangkan daya kritis generasi Z, kekurangan dan kelebihan generasi Z. 


\section{HASIL DAN PEMBAHASAN}

\section{Kurikulum 2013}

Munculnya kurikulum 2013 tidak lain ialah adanya kelemahan pada kurikulum KTSP yang tidak relevan dalam dunia pendidikan di Indonesia. Selain itu kurikulum K13 juga dituntut untuk menghadapi permasalahan dan tantangan masa depan yang semakin kompleks. Adapun tantangan masa depan tersebut ialah berkaitan dengan globalisasi dan pasar bebas, masalah lingkungan hidup, kemajuan teknologi informasi, konvergensi ilmu dan teknologi, ekonomi yang berbasis pengetahuan, kemajuan industry kreatif dan budaya, pengaruh teknosains, mutu, investasi dan transformasi pada sektor pendidikan. Berikut kelemahan-kelemahan yang terdapat pada KTSP 2006 diantaranya: isi dan pesan kurikulum masih bersifat padat, kurikulum belum mengembangkan kompetensi secara utuh sesuai dengan visi, misi dan tujuan pendidikan nasional, kompetensi yang masih bersifat pengetahuan. kurikulum tersebut belum mengakomodasi perkembangan masyarakat, standar pembelajaran masih berpusat pada pendidik, penilaian dalam menggunakan standar penilaian berbasis kompetensi (Mulyasa 2013).

Beberapa kelemahan yang dikemukakan diatas, perlu adanya perubahan dan pengembangan kurikulum. Kurikulum harus mampu mempersiapkan peserta didik dengan berbagai kompetensi. Kompetensi yang diperlukan dimasa depan sesuai dengan perkembangan global. Kemunculan kurikulum 2013 sebagai penyempurnaan dari kurikulum sebelumnya, hal tersebut disusun dengan mengembangkan pada sisi pengetahuan, ketrampilan, dan sikap. Kurikulum 2013 ditekankan dalam pembelajaran yang diarahkan pada penguasaan yang bersifat pengetahuan dan ketrampilan yang dapat mengembangkan sikap spiritual dan sosial. Hal tersebut sesuai dengan tujuan pendidikan nasional yaitu "mengembangkan potensi peserta didik agar menjadi manusia yang beriman dan bertakwa kepada Tuhan Yang Maha Esa, berakhlak mulia, sehat, berilmu, kreatif, mandiri dan menjadi warga negaara yang demokratis serta bertanggung jawab" (Machali 1970). Kurikulum 2013 menekankan pada pengembangan kemampuan, ketrampilan serta aspek karakter dalam melakukan tugas dengan standar performasi tertentu, yang akhirnya akan dirasakan oleh peserta didik terhadap penguasaan kompetensi tertentu. Kompetensi pengetahuan peserta didik yang dikembangkan berupa mengetahui, memahami, menganalisis, menerapkan, dan mengevaluasi agar menjadi individu yang menguasai ilmu pengetahuan, teknologi, budaya dan lain sebagainya. Begitu juga dalam aspek sikap pada aspek menghayati dan sejenisnya. Begitupun juga pada ketrampilan yang meliputi beberapa aspek seperti mengamati dan sejenisnya. Kurikulum ini juga akan menjadi pedoman dalam melaksanakan proses pembelajaran yang lebih efektif baik disekolah maupun luar sekolah. Kurikulum ini jga harus didukung oleh para orangtua dan lingkungan yang ikut andil dalam menyukseskan kurikulum tersebut (Nazila \& Jadid 2019).

Berikut tujuan kurikulum 2013 yang mengacu pada Undang-Undang Nomor 20 Tahun 2003, maka adanya perubahan kurikulum dengan bertujuan "melanjutkan pengembangan kurikulum berbasis kompetensi yang telah dirintis pada tahun 2004 dengan mencakup kompetensi sikap, pengetahuan dan ketrampilan.”. Paparan diatas, kurikulum 2013 akan menghasilkan peserta didik yang kreatif, produktif, dan inovatif dengan cara penguatan sikap, pengetahuan dan ketrampilan. hal tersebut memungkinkan kurikulum 2013 (K13) membentuk potensi dan karakteristik anak didik berupa pengetahuan, sikap dan ketrampilan yang dapat dipraktekkan sebagai wujud pemahaman terhadap mata pelajaran yang telah diajari secara kontekstual. Pencapaian tujuan diatas dengan cara menuntut perubahan pada setiap aspek, terutama pada implementasi dilapangan secara langsung. Pada proses pembelajaran dengan kurikulum 2013 (K13) yang sebelumnya peserta didik "diberi tahu" akan menjadi "mencari tahu". Sedangkan dalam proses penilaian yang awalnya fokus pada "pengetahuan melalui penilaian output" akan menjadi " kemampuan melalui penilaian proses, portofolio dan penilaian output secara utuh dan menyeluruh” (Mulyasa 2013).

Adapun pada aspek manfaat dari pengembangan kurikulum 2013 yaitu ada dua aspek manfaat kurikulum 2013 jika diberlakukan dalam setiap lembaga pendidikan yang dipaparkan ( Poerwati \& Amri 2013) diantaranya: Pertama, Mendorong untuk menciptakan otonomi sekolah dalam 
menyelenggarakan pendidikan. Kurikulum 2013 telah memberikan otonomi secara luas kepada sekolah dan satuan pendidikan guna mengembangkan kurikulum secara sepihak yang sesuai dengan situasi dan kebutuhan daerah masing-masing. Kebijakan pengmbangan kurikulum dan pembelajaran serta evaluasi didesentralisasikan kesekolah dan satuan pendidikan, sehingga pengembangan kurikulum diharapkan sesuai dengan kebutuhan peserta didik dan masyarakat yang fleksibel. Kedua, kurikulum 2013 memberi peluang yang luas kepada sekolah plus untuk mengembangkan kurikulum yang sesuai dengan kebutuhan. Hal ini merupakan kebebasan kepada sekolah plus untuk menyusun yang lebih variasi sebagaimana yang telah ditetapkan pemerintah. Maka dengan ini sekolah plus dapat menyesuaikan dengan kebutuhannya sendiri.

\section{Tuntutan Pengembanga Kurikulum}

Selain adanya kelemahan pada kurikulum sebelumnya, berikut beberapa faktor yang melatarbelakangi adanya pengembangan pada kurikulum 2013 diantaranya: Pertama, tantangan internal: beberapa tantangan yang terjadi dalam internal kurikulum yaitu tuntutan pendidikan yang berdasarkan pada delapan poin standar nasional pendidikan yaitu standar pengelolaan, pembiayaan, sarana prasarana, pendidik dan tenaga kependidikan, isi, proses, standar penillaian dan kompetensi lulusan. Selain itu ada juga dari sisi perkembangan penduduk indonesia yang pertumbuhan usianya makin produktif. Saat ini, usia produktif 15-60 tahun lebih banyak daripada usia tidak produktif 0-14 tahun. Jumlah penduduk usia produtif akan mencapai puncaknya pada tahun 2020-2030 mencapai 70\%. Maka dari itu, sumber daya manusia usia produktif harus mampu dibentuk menjadi yang kompeten melalui pendidikan. Kedua, tantangan eksternal: tantangan eksternal yang dihadapi dunia pendidikan yaitu dunia global yang semakin maju menjadikan tantangan yang harus dihadapi dan bahkan menembus "dinding rumah globalisasi ilmu pengetahuan" seperti kemjuan informasi teknologi dan lain sebagainya. Persepsi masyarakat terhadap pendidikan hanya fokus terhadap kognitif dan kurangnya didikan pada karakter anak. Fenomena negatif yang berimpek pada anak didik berupa adanya perkelahian atau pertengkaran, kelakukan bernarkoba, melakukan plagiasi, melakukan kecurangan dalam ujian dan gejolak masyarakat. Pengembangan pengetahuan berupa neurologi, psikologi, observation based (discovery) learning dan colaborative learning. Ketiga, penyempurnaan pola pikir: Berikut beberapa cara dalam penyempurnaan pola pikir diantaranya yaitu pola pembelajaran yang berpusat pada pendidik berubah menjadi pembelajaran yang berpusat pada peserta didik, pola pembelajaran satu arah berubah menjadi pembelajaran interaktif (interaktif pendidik-peserta didikmasyarakat-lingkungan alam-suber/median dan lainnya), Pola pembelajaran terisolasi berubah menjadi pembelajaran seara jejaring, pola pembelajaran pasif berubah menjadi pembelajaran aktif, pola pembelajaran bersifat individu berubah menjadi pola pembelajaran kelompok/tim, pola pembelajaran berbasis massal berubah menjadi pola pembelajaran sesuai kebutuhan peserta didik untuk mengasah potensinya masing-masing, pola pembelajaran ilmu pengetahuan secara tunggal berubah menjadi pembelajaran ilmu pengetahuan secara jamak, pola pembelajaran pasif berubah jadi pola pembelajaran yang kritis. Keempat, Penguatan Tata Kelola Kurikulum dan Materi diantaranya tata kerja pendidik bersifat individu berubah menjadi tata kerja bersifat bersama/kolaborasi, penguatan manajemen sekolah melalui penguatan kemampuan manajemen pemimpin sekolah sebagai pemimpin kependidikan (education leader), penguatan sarana prasarana sebagai kepentingan manajemen dan proses pembelajaran, penguatan materi digunakan dengan cara pendalaman dan memperluas materi yang relevan pada anak didik (Widyastono, 2014).

\section{Generasi Z}

Secara definisi, menurut ( Bhakti \& Safitri, 2017) generasi Z merupakan anak yang lahir dari sejak tahun 1995-2010. Menurut (Ratnawati \& Aristin, 2016) Dalam penelitiannya ada yang menyimpulkan bahwa generasi Z merupakan generasi yang lahir dari tahun 2000an. Sedangkan menurut (Handayani, 2019) memaparkan bahwa generasi $\mathrm{Z}$ merupakan generasi yang lahir di zaman era digital yang gaya hidupnya telah banyak dipengaruhi oleh tekonologi dan gaya komunikasi yang berkembang pesat. Mereka biasa disebut sebagai generasi iGeneration atau net generation. Generasi ini lahir pada saat internet diciptakan dan berkembang pesat dalam kehidupan manusia dan mereka tidak 
mengenal dengan mainan-mainan tradisional yang dilakukan dengan anak-anak seusianya dahulu. Generasi $\mathrm{Z}$ dikenal juga sebagai generasi digital anak muda yang tumbuh dan berkembang dengan ketergantungan pada teknologi digital. Karakter generasi $\mathrm{Z}$ sangat unik dan berbeda dengan generasi sebelumnya dikarenakan pengaruh dari teknologi sangat kuat bagi mereka seperti ketergantungan pada gadget. Penelitian Fitra menjelaskan bahwa iGeneration biasanya mengaplikasian berbagai kegiatan dalam satu waktu yang biasanya berhubungan dengan dunia maya. Generasi Z juga cederung menggantungkan kegiatan dan aktivitas dimedia sosial (Fitra \& Imam, 2018).

Adapun indikator yang termasuk generasi Z ( Bhakti \& Safitri 2017) diantaranya: Pertama, anakanak berambisi untuk sukses. Hal merupakan karakter yang positif dan optimis dalam menggapai keinginan. Kedua, praktis dan berprilaku instan. Hal ini merupakan kesukaan anak-anak dalam memecahkan masalah yang praktis sebab mereka lahir dalam dunia yang instan. Ketiga, suka dalam kebebasan dan percaya diri sangat tinggi. Anak-anak senang dalam berpendapat, bebas berkreasi, bebas berkespresi dan sejenisya. Sebab mereka lahir dalam dunia modern, yang sebagian besar menyukai pelajaran eksplor sebab mereka tidak menyukai pelajaran yang bersifat hafalan. Keempat, menyukai halhal yang detail. Mereka termasuk anak-anak kritis dalam berfikir, detail dalam mencermati masalah sebab mereka sangat mudah dalam mencari informasi dengan teknologi. Kelima, cenderung ingin mendapatkan pengakuan. Mereka sangat senang mendapatkan pujian dan sejenisnya dikarenakan kemampuan yang dimiliki setiap individu. Keenam, digital dan informasi. Generasi Z sangat cerdas dalam menggunakan segala bentuk gadget untuk digunakan dalam kebutuhan hidupnya.

\section{Kekurangan dan Kelebihan Generasi Z}

Dalam setiap generasi mempunyai kekurangan dan kelebihan, begitupun yang terjadi dengan generasi Z. dengan kecanggihan pada masanya tidak menutup kemungkinan dengan berbagai kekurangan dan kelebihan. Berikut beberapa kekurangan dan kelebihan pada generasi $Z$ yaitu pertama, kekurangan yang terjadi dalam generasi $\mathrm{Z}$ diantaranya sering tidak sabaran dalam menghadapi sesuatu, selalu menyelesaikan masalah dengan instan dikarenakan terbiasa berkomunikasi dengan dunia maya yang praktis, kurang berkomunikasi secara verbal yang mengakibatkan ketidak perdulian dengan lingkungan, beberapa dari kalangan generasi Z kurang terampil. Kedua, kelebihan yang terjadi dalam generasi $\mathrm{Z}$ diantaraya keinginan dalam mengetahui segala sesuatu sangat tinggi, usaha adpa menguasai yang menjadi kebutuhannya dan mampu mengaplikasian teknologi dan mempunyai sifat multitasking (Bhakti \& Safitri 2017)

\section{Strategi Implementasi Kurikulum 2013}

Berikut beberapa aspek dalam strategi impelementasi yang harus diperhatikan dalam melaksanakan kurikulum 2013 diantaranya: Pertama, pelaksanaan kurikulum pada seluruh lembaga pendidikan telah dilakukan pada 3 tahun terakhir yaitu bulan juli 2013 di kelas I, IV terbatas pada sejumlah SD/MI (30\%) dan seluruh VII (SMP/MTS) dan X (SMA/MA, SMK/MAK). Ini merupakan tahun awal dalam pengimlementasian diseluruh wilayah. Adapaun untuk SD akan dipilih 30\% SD dari setiap kabupaten/kota disetiap provinsi. Pada bulan juli 2014 dikelas I,II,IV,V,VII,VIII,X,XI. Tahun kedua implementasi kurikulum 2013. Dan untuk setara SD akan dipilih lagi 30\% agar menjadi 60\% implementasi kurikulum ini diseluruh wilayah. Pada tahun kedua ini, hanya kelas terakhir pada jenjang SMP atau MTS, SMA atau MA dan SMK atau MAK yang belum melaksanakan kurikulum. Pada bulan juli 2015 diseluruh kelas dan seluruh lembaga sekolah SD sampai SMA telah melaksanakan kurikulum 2013 sepenuhnya. Kedua, pelatihan guru, kepala sekolah dan pengawas. Hal ini diawali pada tahun 2014 sampai tahun 2016, pelathan guru, kepala sekolah dan pengawas yang akan melaksanakan kurikulum 2013 akan mendapatkan pelatihan untuk efisiensi kurikulum tersebut. Pelatihan ini dimulai dengan dengan kegiatan persiapan (pennyiapan buku peserta didik dan buku guru. Serta evaluasi dan pendampingan guru dalam implementasi kurikulum 2013. Ketiga, pengembangan buku babon. Penulisan dan percetakan buku babon merupakan bagian dari strategi implementasi kurikulum 2013. Buku babon terdiri dari buku peserta didik dan buku pendidik. Adapaun isi buku pendidik sama dengan buku babon peserta didik akan tetapi buku pendidik ditambahkan dengan strategi pembelajaran dan penilaian hasil belajar. Sedangkan pedoman pembelajaran dan penilaian telah 
dicantumkan dalam buku pedomannya sendiri. Keempat, pengembangan manajemen, kepemimpinan, sistem administrasi dan budaya sekolah. Upaya mewujudkan kurikulum 2013 harus menata kembali manajemen, administrasi, kepemimpinan dan budaya yang baru. Untuk itu, pelatihan harus berkenan dengan tata kerja baru untuk guru dan pemimpin sekolah sebagai upaya dalam mendorong terciptanya K13 agar tidak hanya sebatas rencana akan tetapi adanya perbaikan pada pelaksanaan pendidikan pada setiap lembaga pendidikan. Kelima, pendampingan dalam bentuk monitoring dan evaluasi. Strategi dalam mewujudkan K13 tidak lagi menggunakan pelatihan one-shot dikarenakan banyaknya kelemahan pelatihan tersebut. pelatihan yang digunakan untuk pendidik, pemimpin sekolah dan pengawas akan diikuti dengan monitoring dan evaluasi sepanjang pelaksanaan minimal 3 tahun perjalanan kurikulum 2013. Harapan terwujudnya K13 ini agar setiap masalah setelah berjalan 3 tahun dapat diatasi oleh para pendidik, pemimpin sekolah maupun pengawas pada setiap wilayah (at-Taubany \& Suseno 2017)

\section{Kurikulum 2013 Berbasis Kompetensi Sebagai Pengembangan Individu Generasi Z}

Pada dasarnya kompetensi merupakan paduan antara pengetahuan, sikap dan ketrampilan yang dapat direfleksikan dalam kebiasaan berfikir dan tindakan. Menurut Burkey (1995) mengatakan bahwa kompetensi merupakan pengetahuan, sikap dan ketrampilan yang mampu dikuasai oleh individu sehingga mampu diwujudkan baik dari segi kognitif, afektif maupun psikomotik. Penilaian terhadap pencapaian kompetensi perlu dilakukan dengan cara objektif yang didasari dengan kinerja anak didik yang sesuai dengan penguasaan pada pengetahuan, sikap dan ketrampilan sebagai nilai hasil belajar. Dengan hal tersebut pembelajaran yang dirancang berdasarkan kompetensi, penilaian tidak dapat dilakukan dengan cara pertimbangan yang bersifat subjektif (Mulyasa 2013).

Berikut beberapa uraian aspek yang terdapat dalam konsep kompetensi diantaranya: pertama, pengetahuan yang merupakan kesadaran diri terhadap seseorang yang memiliki pengetahuan atau biasa disebut kognitif. Contoh, pendidik mengetahui cara melakukan identifikasi kebutuhan belajar dan bagaimana melakaukan pembelajaran terhadap peserta didik yang sesuai dengan kebutuhannya. Kedua, pemahaman sebagai pendalaman kognitif dan afektif yang dimiliki setiap indvidu. Contoh, pada proses pembelajaran, pendidik mengetahui cara mengajar dengan kreatif dengan mengidentifikasi kebutuhan belajar serta memiliki pemahaman yang baik sesuai dengan karakter dan kondisi anak didiknya guna mewujudkan proses belajar yang efektif. Ketiga, kemampuan merupakan sesuatu yang dimiliki setiap individu dalam melakukan tugas yang diberikan kepada setiap individu. Contoh, pendidik kreatif dalam memilih dan menggunakan alat peraga guna sebagai jembatan atau media dalam memberikan kemudahan pada proses pembelajaran kepada anak didik yang diajari. Keempat, nilai merupakan suatu standar prilaku yang telah diyakini dan secara psikologis telah menyatu pada dirinya sendiri. Contoh, standar prilaku pendidik pada proses pembelajaran seperti jujur, terbuka, objektif, demokratis dan lain sebagainya). Kelima, sikap merupakan perasaan (senang atau tidak senang, suka atau atau tidak suka dan sejenisya) dan reaksi terhadap suatu rangsangan yang datang dari luar. Contoh, reaksi terhadap krisis ekonomi, perasaan terhadap kenaikan upah/gaji, adanya masalah keluarga, sedang merasa kecewa pada atasan dan lain sebagainya. Keenam, minat merupakan kecenderungan individu dalam melakukan suatu perbuatan. Contoh, minat untuk melakukan atau mempelajari sesuautu hal yang baru. Berdasarkan paparan diatas, kurikulum 2013 (K13) berbasis kompetensi diartikan juga sebagai konsep kurikulum yang memfokuskan terhadap pengembangan dam kemampuan melakukan (kompetensi) tugas dengan standar performasi tertentu yang kemudian hasilnya dapat dirasakan oleh peserta didik. Kurikulum 2013 diarahkan untuk mengembangkan pengetahuan, pemahaman, kemampuan, nilai, sikap dan minat peserta didik agar dapat melakukan sesuatu dalam bentuk keberhasilan dengan tanggung jawab sepenuhnya. Selain itu, dalam kurikulum 2013 setidaknya ada 3 hal yang perlu diperhatikan dalam pengembangan yang berbasis kompetensi yaitu penetapan kompetensi yang ingin dicapai, pengembangan strategi untuk mencapai kompetensi dan evaluasi. Kompetensi yang akan dicapai merupakan pernyataan tujuan yang hendak diperoleh peserta didik, menggambarkan hasil belajar pada ranah pengetahuan, sikap, nilai dan ketrampilan. strategi dalam mencapai kompetensi merupakan upaya dalam membantu peserta didik untuk menguasai kompetensi yang telah ditetapkan. Contoh, membaca, mendengarkan, menulis, berkreasi dan mengobservasi sampai terbentuk 
kompetensi. Adapun evaluasi sebagai kegiatan penilaian terhadap pencapaian kompetensi bagi setiap peserta didik (Mulyasa 2013).

\section{Metode Pembelajaran Kurikulum 2013 Dalam Mengembangkan Daya Kritis Generasi Z}

Kurikulum 2013 merupakan desain dan perangkat yang baru dan hasil dari pembaharuan dari kurikulum sebelumnya. Disebabkan adanya penyiapan dalam membangun dan menyiapkan generasigenerasi bangsa yang sesuai dengan kebutuhan dan tantangan zaman. Maka dari kurikulum 2013 sangat efektif dan ideal digunakan dalam masa teknologi demi terciptanya generasi teknolog yang beran baik dalam dunia nyata maupun dalam dunia maya sebagai penerus generasi bangsa dan kemajuan bangsa itu sendiri. Pembelajaran yang harus disiapkan dalam merubah cara pendidik dalam mengajarkan anak generasi $\mathrm{Z}$ harus berbeda dengan pembelajaran terdahulu. Generasi Z tidak lagi membutuhkan transformasi ilmu tradisional yang bersifat penyampaian materi dari guru ke anak didik. Akan tetapi yang dibutuhkan ialah cara anak didik dalam mengatasi masalah dengan kritis dan sistematis.

Berikut dua (2) metode pembelajaran dalam meningkatkan dan mengembangkan anak didik diantaranya: Pertama, Problem Based Learning: Metode ini dapat meningkatkan keaktifan anak untuk berpikir kritis dan analitik. bahwa problembased learning merupakan metode dalam membantu anak untuk mengembangkan kemampuan berfikir, mengatasi maslah, ketrampilan penyelidikan dan kemampuan mempelajari peran sebagai orang dewasa melalui keterlibatan dalam pengalaman nyata atau simulasi. Proses pembelajarannya ialah peserta didik diberi masalah yang akan disajikan yang sesuai dengan konteks dunia nyata agar dapat meningkatkan kecakapan anak. Setelah masalah diberikan, anak didik membagi kelompok dan bekerjasama lalu mencoba memecahkan masalah yang diberikan. Mereka mencoba mencari informasi yang relevan. Hal ini menjadikan pengetahuan anak dibangun dan menemukan solusi secara mandiri. Dan pendidik sebagai fasilitator dan mengarahkan anak-anak dalam mencari solusi permasalahan. Dengan metode ini, pengetahuan bukan hanya seperangkat fakta, konsep atau kaidah yang hanya sebatas ingatan akan tetapi dapat merekonstruksi pengetahuan dan mendapatkan makna melalui pengalaman (Widodo \& Widayanti, 2013). Kedua, Cooperatif Learning: bersifat kontrukivis yang mana anak didik dituntut dan membangun pegetahuan secara mandiri. Anak didik akan dikelompokkan 3-6 orang setiap kelompok. Kemudian materi akan disajikan kepada anak didik dalam bentuk teks dan setiap anak didik bertanggung jawab untuk mempelajari materinya. Kemudian tiap anggota dari kelompok yang berbeda akan menyampaikan topiknya sendiri kepada kelompok lain untuk saling belajar dan membantu dalam mempalajari topik. Lalu anak kembali kekelompok asalnya dan mengajarkan materi yang telah didapatkan kekelompok asalnya. Setelah diskusi pada kelompok asal, anak mengerjakan kuis secara mandiri tentang berbagai materi yang telah didapatkan. Pembelajaran seperti ini akan melatih anak dalam menangkap materi dan belajar menyampaikan materi dari anak ke anak lainnya (Agustina, Nugroho, \& Mulyani, 2013).

\section{SIMPULAN DAN SARAN Simpulan}

Kurikulum 2013 harus disiapkan dan dilaksanakan dari beberapa aspek diantaranya pelaksanaan kurikulum diseluruh jenjang pendidikan, Pelatihan guru, kepala sekolah dan pengawas, pengembangan buku babon pengembangan manajemen, kepemimpinan, sistem administrasi dan budaya sekolah, pendampingan dalam bentuk moitoring dan evaluasi. Kurikulum 2013 berbasis kompetensi sebagai dasar dalam mengembangkan individu generasi $\mathrm{Z}$ ditinjau dari beberapa aspek yang harus diperhatikan oleh pendidik untuk membentuk peserta didik yaitu pengetahuan, pemahaman, kemampuan, nilai, sikap dan minat anak didik. Kurikulum 2013 sebagai konsep dan strategi dalam meningkatkan daya kritis generasi $\mathrm{Z}$ yang disebabkan adanya penyiapan dalam membangun generasi-generasi bangsa yang sesuai dengan kebutuhan dan tantangan zaman. Maka dari itu kurikulum 2013 sangat efektif dan ideal digunakan dalam masa teknologi demi terciptanya generasi teknolog yang berperan baik dalam dunia nyata maupun dalam dunia maya sebagai penerus generasi bangsa dan kemajuan bangsa itu sendiri. 
162 Instructional Development Journal (IDJ), Vol. 3, No. 3, Desember 2020, Hal. 155-162

Pembelajaran yang harus disiapkan dalam merubah cara pendidik dalam mengajarkan anak generasi Z harus berbeda dengan pembelajaran terdahulu.

\section{Saran}

Pendidikan merupakan wadah dalam membentuk manusia seutuhnya salah satunya pembentukan akal pikiran yang kritis dan sistematis. Mengacu pada kurikulum 2013 semestinya mampu membentuk daya kritis generasi bangsa yaitu generasi $\mathrm{Z}$ sebagai bentuk dalam mempersiapkan regenerasi bangsa masa depan yang baik. Maka dari itu, sudah semestinya pendidikan tidak bersifat transformasi ilmu, akan tetapi pembentukan pikiran yang kritis agar dapat dikontekstualisasikan dalam kehidupannya masing-masing.

\section{DAFTAR RUJUKAN}

Agustina, E., Saputro, A. N. C., \& Mulyani, S. (2013). Penggunaan metode pembelajaran jigsaw berbantuan handout untuk meningkatkan aktivitas dan prestasi belajar siswa pada materi pokok hidrokarbon kelas xc sma negeri 1 gubug tahun ajaran 2012/2013. Jurnal Pendidikan Kimia Universitas Sebelas Maret, 2(4), 66-71.

Endah Loeloek, P. (2013). Panduan Memahami Kurikulum 2013 Sebuah Inovasi Struktur Kurikulum Penunjang Masa Depan. Jakarta: Prestasi Pustaka Karya.

Siagian, H. F., \& Fachrurrazi, T. I. (2019). Implementasi Zetizen Bagi Daya Tarik Literasi Media Generasi Z. Jurnal Jurnalisa: Jurnal Jurusan Jurnalistik, 4(1).

Handayani, I. (2019). Konsep Bimbingan dan Konseling Pribadi-Sosial dalam Pengembangan Positive Mental Attitude Generasi Z. NALAR: Jurnal Peradaban dan Pemikiran Islam, 3(1), 51-63.

Machali, I. (2014). Kebijakan perubahan kurikulum 2013 dalam menyongsong Indonesia emas tahun 2045. Jurnal Pendidikan Islam, 3(1), 71-94.

Mulyasa, E. (2013). Pengembangan Dan Implementasi Kurikulum 2013. Cetakan pertama. Bandung: PT Remaja Rosdakarya.

Nazila, F. (2019). Strategi Implementasi Kurikulum 2013 di Era Disrupsi. FONDATIA, 3(1), 1-10.

Purnomo, A., Ratnawati, N., \& Aristin, N. F. (2017). Pengembangan Pembelajaran Blended Learning Pada Generasi Z. Jurnal Teori dan Praksis Pembelajaran IPS, 1(1), 70-76.

Bakti, C. P., \& Safitri, N. E. (2017). Peran bimbingan dan konseling untuk menghadapi generasi Z dalam perspektif bimbingan dan konseling perkembangan. Jurnal Konseling GUSJIGANG, 3(1).

Taubany, T.I.B., \& Suseno, H. (2017). Desain Pengembangan Kurikulum 2013 Di Madrasah. Cetakan ke 1. Depok: Kencana.

Widayanti, L. (2013). Peningkatan aktivitas belajar dan hasil belajar siswa dengan metode problem based learning pada siswa kelas VIIA MTS Negeri Donomulyo Kulon Progo tahun pelajaran 2012/2013. Jurnal Fisika Indonesia, 17(49).

Widyastono, H. (2014). Pengembangan Kurikulum Di Era Otonomi Daerah: Dari Kurikulum 2004, 2006 Ke Kurikulum 2013. Cetakan pertama. Jakarta: Bumi Aksara. 